\title{
Biologists question adult stem-cell versatility
}

Natalie DeWitt and Jonathan Knight

A fresh debate has broken out over the importance of adult stem cells, in the wake of new evidence that their potential usefulness in medicine has been exaggerated.

Many researchers believe that embryonic stem cells, which can develop into any type of cell in the body, could revolutionize treatments for conditions ranging from heart disease to Parkinson's disease. Those opposed to such research, because it involves killing human embryos, have touted adult stem cells as an alternative. And over the past two years, evidence has mounted that adult cells may be almost as malleable as embryonic cells.

But two papers published on Nature's website on 13 March (DOIs: 10.1038/ nature $729 ; 10.1038 /$ nature 730 ) raised doubts about the validity of those results, according to researchers attending a scientific conference on stem cells in Keystone, Colorado.

Stem cells in the adult body have limited options. Certain stem cells from bone marrow, for example, can form only blood. But several reports in the past two years have hinted that blood precursor cells can form other tissues, such as brain cells, if they are first incubated with embryonic stem cells.

The Nature papers suggested an alternative explanation. Rather than switching their fate - a phenomenon known as transdifferentiation - the adult cells might actually be fusing with the embryonic cells to become an entirely new type of cell. Fused cells might be too abnormal to be of medical use.

Rudolph Jaenisch, a biologist at the Whitehead Institute for Biomedical Research in Cambridge, Massachusetts, set the tone of the meeting when he mentioned the two Nature papers in his keynote address and

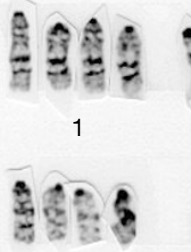

6
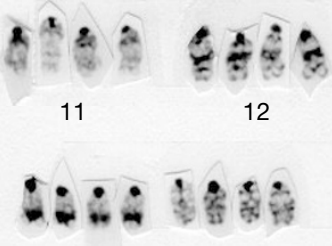

16
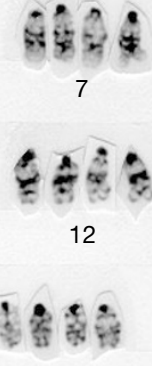
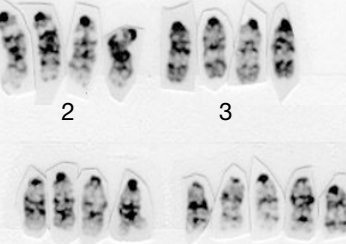

8

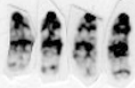

4

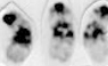

5

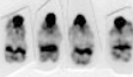

13
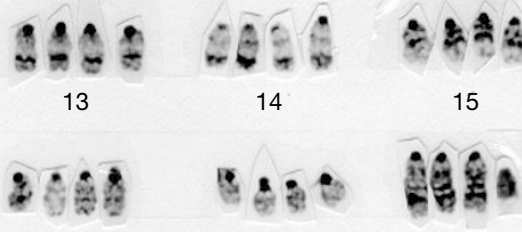

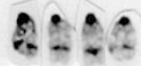

9

15

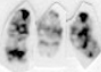

10

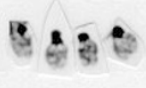

$X Y$

No transdifferentiation: adult bone marrow cells from mice fuse with embryonic cells, resulting in too many copies of each chromosome, according to a team led by the University of Florida's Naohiro Terada.

suggested that all of the evidence for transdifferentiation should now be re-evaluated.

Subsequently, a succession of stem-cell researchers gave talks in which they said they had been unable to confirm the reported versatility of adult cells in their labs. Stanford University biologist Irving Weissman said his group had failed to replicate the transdifferentiation experiments. And Ihor Lemischka, a molecular biologist at Princeton University, told the meeting that stronger evidence for the plasticity of adult stem cells was needed.

Scientists who have reported transdifferentiation said they would look for evidence of fusion, but had no reason to suspect that it accounted for their results. Diane Krause of Yale University, who generated one of the most celebrated adult stem-cell results last

\section{Toxic transfer gets cool response}

Virginia Gewin, Washington

Members of Congress and environmentalists are rallying against a proposed transfer of some water-quality research programmes from the US Geological Survey (USGS) to the National Science Foundation (NSF).

The transfer of the Toxic Substances Hydrology Program, proposed by President Bush as part of his budget in February (see Nature 415, 565; 2002), would also involve a \$22-million cut in funding for the programme, which analyses the concentration of biological and chemical pollutants in streams and rivers. A similar cut was proposed by the administration last year, and was rebuffed by Congress.

Representative Ron Kind (Democrat, Wisconsin) has drafted a letter urging the appropriations subcommittee responsible for the USGS to maintain this year's budget for the water programmes, and to dismiss the transfer. The letter is being circulated to other representatives for signature.

The results of a USGS study released last week - the first to document levels of 82 compounds, including reproductive hormones, in streams across the country prompted 40 environmental groups to call for the programme to remain at the USGS.

"The USGS is the ideal institution to conduct nationwide surveys such as this one," says Margaret Mellon, head of the food and environment programme at the Union of Concerned Scientists. Critics say that the programme would change beyond recognition if it was transferred to the NSF. year (see Cell 105, 369-377; 2001), said that her transdifferentiated stem cells contained a normal number of chromosomes, whereas a fused cell should have twice the normal number. Others countered that cells can shed extra chromosomes and might return to the normal number after a few generations.

Adult stem cells may find a use in medicine even if they don't transdifferentiate, says Ronald McKay of the National Institutes of Health in Bethesda, Maryland. He says his colleague Donald Orlic has shown that bonemarrow cells can repair heart-attack damage in rodents, although the mechanism involved is unclear (Nature 410,701-705; 2001).

Catherine Verfaillie of the University of Minnesota, who is studying stem cells from bone marrow that appear capable of forming any tissue in the body, says she has not yet had time to test whether cell fusion played a part in her findings, but that she would do so.

The fusion argument is likely to come up in the Senate in debates there over a bill introduced by Sam Brownback (Republican, Kansas) that would ban human cloning. The nuclear-transfer procedure used in cloning could also be used to produce genetically compatible embryonic stem cells for individual patients. Brownback has argued that adult stem cells make this unnecessary, as they can be taken directly from the patient. "There is no doubt that fusion will be discussed in the Senate hearings," says McKay

Brigid Hogan, a cell biologist at Vanderbilt University School of Medicine in Nashville, says that research on adult stem cells will ultimately benefit from the fusion controversy because it will create new standards for proving that transdifferentiation is possible. "Rigorous standards must be set if people are going to talk about using adult stem cells as a clinical solution," she says. 